Thinking with an Accent: Françoise Collin, Les cahiers du Grif, and French Feminism Author(s): Rosi Braidotti

Source: Signs, Vol. 39, No. 3 (Spring 2014), pp. 597-626

Published by: The University of Chicago Press

Stable URL: http://www.jstor.org/stable/10.1086/674299

Accessed: 22/01/2015 09:13

Your use of the JSTOR archive indicates your acceptance of the Terms \& Conditions of Use, available at http://www.jstor.org/page/info/about/policies/terms.jsp

JSTOR is a not-for-profit service that helps scholars, researchers, and students discover, use, and build upon a wide range of content in a trusted digital archive. We use information technology and tools to increase productivity and facilitate new forms of scholarship. For more information about JSTOR, please contact support@ jstor.org. 


\section{Thinking with an Accent: Françoise Collin, Les cahiers du Grif, and French Feminism}

rançoise Collin was an institution in her own right. She was the cofounder, in 1973, of the first and most influential French-language feminist journal, Les cahiers du Grif(Notebooks of Grif), which moved to Paris from Brussels in 1982. ${ }^{1}$ That same year, I joined the editorial board, and I worked closely with Françoise until 1990.

As a French-speaking Belgian, Collin never quite fit into any nationally indexed classification system. She was first and foremost a sharp critical spirit, an activist, and a multifaceted writer. This stance of defiant independence - even at the cost of marginalization - as well as her intellectual gifts are what made her attractive to younger feminists. ${ }^{2}$ I belong to an "intermediate" feminist generation (Braidotti 2010, 227) that was magnetically attracted to Paris by the originality and daring of the great thinkers who were to become known as the poststructuralists, or the philosophers of difference. Given that the great minds of Paris never had much time for their students, however, we organized our own study group to supervise our respective dissertations collectively. We were graduate students from Australia, the United States, the United Kingdom, Canada, and a broad range of European countries. ${ }^{3}$ We mostly attended Michel Foucault and Roland Barthes's lectures at the Collège de France; the courses of Marcelle Marini (1977), Julia Kristeva (1984), and Michelle Perrot (1984) at Université Paris VII; and seminars with Gilles Deleuze (1968), François

My thanks go to Sylvie Duverger, Geneviève Fraisse, Goda Klumbyte, Anya Kopolski, Mara Montanaro, and Pierre Taminiaux and especially to Joan Scott, Penelope Deutscher, Henrietta Moore, Annamaria Tagliavini, and Nadine Plateau for their editorial advice.

1 "Grif" is an acronym for Groupe de Recherche et d'Information Féministe (Feminist Research and Information Group).

2 Magda Michielsens $(2011,19)$ has insightfully labeled Collin's stance "une marginalité revendiquée" (a self-conscious marginalization).

${ }^{3}$ Participants were Mia Campioni, Claire Duchen, Anna Gibbs, Nancy Huston, Alice Jardine, Meaghan Morris, Jane Weinstock, Teresa Brennan, Jane Gallop, myself, and many others. The slightly older generation was also present: Danielle Haase-Dubosc, Domna Stanton, Kate Stimpson, Naomi Schor, and Nancy Miller visited regularly. These were the days when Laurie Anderson was busking in the Latin Quarter. Jane Weinstock introduced us to an impressive young photographer named Barbara Kruger, while Marie Schneider used to hang out at feminist film festivals with her girlfriend. For more details, see Braidotti (2011).

[Signs: Journal of Women in Culture and Society 2014, vol. 39, no. 3]

(c) 2014 by The University of Chicago. All rights reserved. 0097-9740/2014/3903-0008\$10.00 
Châtelet (1970), Hélène Cixous (1976a), and Jean-François Lyotard (1979) at Université Paris VIII, Vincennes.

The seminars Collin organized in the autonomous feminist space of Les cabiers du Grif, however, were something else. We often traveled to Brussels to attend events in this mythic location in la Rue Blanche. Those early gatherings shaped several generations of feminists (Michielsens 2011) and raised issues that remain relevant for the contemporary agenda. Les cahiers du Grif combined the highest standards of intellectual rigor with flights of invention that inspired us and freed our own theoretical imagination. The journal embodied the perfect mixture of the theoretical and the political - it was smart and intellectually up to date but also engaged in a militant vein that echoed our own activism. It connected the intellectual feminist elites with the militant base of the movement. For us, Collin's group was the substitute for a feminist graduate school that did not exist in the institutions as yet. It would take years to become institutionalized, thanks to the efforts of the many of us who had been self-taught graduate students. Back then, we were simply awestruck by what the women of Les cahiers du Grif were achieving.

\section{Les cahiers du Grif}

Les cabiers du Grif was based in Brussels from 1973 to 1978; after a brief pause it started up again in Paris in 1982 and ran until 1997. The Belgian part of its existence has been well documented (Brau 2007; D'Hooghe 2011), but not the French years. ${ }^{4}$

The journal was established after the first major general mobilization by Belgian women in 1972, which brought together the many feminist collectives of the day. Given the geographical location of Belgium, feminist activists were closely connected to both Dutch and French dynamic feminist groups. One of their first activities was to draft a Petit livre rouge des femmes (Women's little red book), modeled on the Chinese revolutionary text, which sold thousands of copies. The next action was to start an autonomous journal that might reflect the diversity of viewpoints and political positions of the movement. Dozens of women gathered in the basement of Collin's house in Brussels and paid out of their own pockets to fund this daring new initiative. This is how Les cabiers $d u$ Grif started. ${ }^{5}$

${ }^{4} \mathrm{I}$ have relied on my personal diaries to reconstruct this latter period.

${ }^{5}$ According to Jacqueline Brau (2007), the following women were key participants alongside Collin herself: Marie Denis, Jacqueline Aubenas, Hedwige Peemans-Poullet, Suzanne van Rockeghem, Jeanne Vercheval, Eliane Boucquey, Marthe van de Meulebroecke, Geneviève Simon, and Marie-Thérèse Cuvelliez. 
The first issue - titled "What Is Feminism For?" — had a print run of 1,500. Nineteen more issues were published through 1978, covering a variety of topics, from the most militant to the more theoretical. The journal quickly acquired its distinctive features: combining practical aspects with intellectual topics and giving space to the arts, literature, cinema, and creative work by women.

The quest for the operational rules for what was, after all, an altogether new political game remained a constant of Les cabiers $d u$ Grif. The golden rule of separatism was firmly implemented: no men were ever allowed in the collective or on the editorial board. In the Belgian period, no male authors were welcome at all, but in the Paris period male contributors were published, although only in small numbers. From the beginning, Les cabiers $d u$ Grif allowed authors to sign their articles, which was rather unusual in the women's movement of the time, all production being considered collective and authorship a mode of capitalist appropriation. Another important rule of this journal was discontinuity: different teams took turns in the preparation of the issues, without central control. The only constant factors in those early years were Collin's frequent editorials and the location of the offices in the basement of her house.

Les cabiers du Grif was the first journal to publish both French and European women who later would become internationally recognized. For instance, Luce Irigaray (1974b) appears as early as the third issue in 1974, where she announces the forthcoming publication of her now-classic Speculum of the Other Woman (1985a). Irigaray then returns later the same year and again in 1976 with extracts of her forthcoming This Sex Which Is Not One (see, respectively, Irigaray 1974a, 1976, 1985b). Kristeva also makes an early appearance in 1975 and Cixous in 1976 (Kristeva 1975; Cixous 1976b). Canadian novelist Nancy Huston was a regular contributor alongside other Canadians like Nicole Brossard (1977) and Louise Vandelac (1977a, 1977b). ${ }^{6}$ Also featured were Françoise Héritier (1984), the award-winning actress Delphine Seyrig (1983), the Italians Elena Giannini Belotti (1975) and Maria Antonietta Macciocchi (1979), as well as pioneer feminist filmmakers Agnès Varda (1976) and Jutta Brückner (Collin 1982).

The reception of Les cabiers du Grif was phenomenal, especially in France, Quebec, and French-speaking Switzerland and northern Africa. Its success supported the new women's movement's political campaigns and grassroots activities. But the very conditions that fueled the creative energy of the movement also set its limitations: by 1978 the founding mem-

\footnotetext{
${ }^{6}$ For Huston's contributions, see Huston (1976a, 1976b, 1983a, 1983b).
} 
bers wanted to move on, as feminism started to take different forms and to be disseminated in even more complex ways across a spectrum of social and political institutions. The Belgian collective split into two separate groups: one, led by Marie Denis, Jacqueline Aubenas, and Jeanne Vercheval, went on to fund the new magazine Voyelles (Vowels); the other, with Collin and Hedwige Peemans-Poullet, chose the path of in-depth reflection and founded the Women's University in Brussels. A conference on motherhood in 1979 formalized this partition. By 1980-81, however, Peemans-Poullet and Collin's disagreements caused them to split: the former legally registered the Women's University and founded a new journal (Chronique féministe) in 1982, and the latter moved to Paris to continue Les cahiers du Grif (Brau 2007). The differences between them were ideological as well as tactical: Collin was very committed to the analysis of the cultural and symbolic aspects of the feminist struggle, while Peemans-Poullet gave priority to socioeconomic issues.

These evolutionary bifurcations, internal splits, and constant dealings with the legal and financial structures of self-run feminist projects form an integral part of the early history of all women's movements of the second feminist wave. What makes Les cabiers du Grif significant is the extraordinary pioneering role it played in the French-speaking world. The journal set a creative, original, and visionary political and intellectual agenda. It scouted talent among the best feminist minds of its era, it gave a glimpse of what women's universities and women's studies curricula could look like, it foregrounded the importance of the visual arts and cinema as vehicles for the feminist political imagination, and it continued to attract younger women to the feminist cause, right through to the end. ${ }^{7}$ Its achievement is unique: Les cahiers $d u$ Grif is a monument to European feminism, and Françoise Collin was the force behind it.

\section{The reluctant French feminist}

Collin moved to Paris at a time of great political turmoil, and the independent stance she took in relation to French feminism was important for my generation. She was neither part of the Psychanalyse et Politique group of Antoinette Fouque, who set up the publisher Éditions des Femmes and edited the magazine des femmes hebdo (Women's weekly magazine), nor of Simone de Beauvoir's entourage, who gathered round the journal

\footnotetext{
7 The continuing ability to attract younger women is testified to by Penelope Deutscher, who met Collin in 1995; Anya Toposki, who met her in 2009; and Mara Montanaro, who met her in 2010 (see Montanaro 2012).
} 
Les temps modernes (Modern times), which from 1973 devoted the special section "Chroniques du sexisme ordinaire" (Chronicles of everyday sexism) to feminist issues. Collin also took a critical distance from the Marxist historical materialist feminists led by Christine Delphy, who founded the interdisciplinary social sciences journal Questions féministes (later Nouvelles questions féministes). She worked closely with the feminist historians, such as Genèvieve Fraisse, who gathered around Michelle Perrot, who edited the feminist history journal Pénélope. Collin also collaborated with the literary group that produced the journal Sorcieres (Witches), but as a philosopher she was on her own. She never became assimilated into the socialistfeminist elite that was dominant in the government after the presidential victory of François Mitterand in May 1980. She was different and nonaligned.

Collin's ability to strike a sternly independent intellectual line became especially important amid the quarrels and divisions that marred the French women's movement of those days. The theoretical roots as well as the personal dimensions of these quarrels have been analyzed with great lucidity by Claire Duchen (1986). The major split was between the Marxist socialist feminists, led by Delphy $(1975,1984)$, a sociologist who was close to Beauvoir, on the one hand, and the more psychoanalytically minded Lacanian feminists, led by Fouque (1982), on the other. The clash intensified after Fouque registered the initials of the women's movement-MLF (for mouvement de libération des femmes [women's liberation movement]) —as her personal trademark, causing much distress and litigation among the French feminists.

This quarrel was exacerbated by another important factor: the connection to American feminism. In the same years that I met Collin in Paris, in 1981-82, I also crossed paths with great American academic feminists like Catharine R. Stimpson, Nancy Miller, Domna C. Stanton, Joan Scott, and Naomi Schor, who were carefully following the new developments in France during this period and translating them into English. This was to become the "Franco-American dis-connection" (Stanton 1980, 1987) that would make "new French feminism" (Marks and Courtivron 1980) into a global phenomenon. ${ }^{8}$ Collin was caught in the midst of this and tried to strike a dissonant note.

The American feminists in Paris at the time were especially taken with the psychoanalytic and semiotic aspects of the new French feminism and made sure that these were translated and exported to the United States.

\footnotetext{
${ }^{8}$ Jane Weinstock and I published a critical review of this phenomenon in 1980 (Braidotti and Weinstock 1980).
} 
Delphy (1995) was among the first to complain about the partial selection American scholars were making of French feminist works, fearing that their appropriation produced a false image of what was really happening in France. From the opposite end of the political spectrum, Fouque expressed her concern about the effects of translation on the French theories themselves and about how they mutated into either essentialist theories of difference or femino-phobic queer theories. All the important differences among the French-speaking theorists and activists seemed to be lost in translation and to become amalgamated into a falsely unified whole. The political edge of these theories was considerably weakened as a result. ${ }^{9}$

This polemic gets surreal if you consider that none of the three key figures of new French feminism - Cixous, Kristeva, and Irigaray-are native French. Cixous is a Jewish Algerian, Kristeva came from Bulgaria as a refugee, and Irigaray is Belgian, like Collin. Why Collin was excluded from this marketing and export of ideas is a question worth researching. I would argue that her own independent and critical personality played a major role in her resistance to what she perceived as a gesture of appropriation. Her attachment to the French language and a deep mistrust of translations of her own work also played a role. Kristeva grew to claim her international status as a French cosmopolitan subject, Cixous settled in the position of the constitutive outsider, and Irigaray reiterated her desire to be elsewhere altogether, whereas Collin stayed exactly where she was and claimed the inner complexities of her specific location.

Jacques Lacan, Jacques Derrida, Foucault, Deleuze, and their feminist counterparts Sarah Kofman, Kristeva, Cixous, Irigaray, and others also got caught in a new academic process: the orchestrated import of French ideas into the United States, which made "traveling theories" (Said 1983) into an established practice and turned the task of translation into a new discursive political economy. The epicenter of the new philosophical developments was still Paris, but a widespread diaspora of poststructuralist ideas emerged throughout American academic institutions, mostly in literary theory, comparative literature, cultural and gender studies, and film theory. The impact of French thought on international feminist theory and practice was nothing short of an epistemological revolution. ${ }^{10}$ In the mid1980s, as US feminism plunged into the "sex wars" that would divide its radical wing (Vance 1984), the notion and politics of difference moved to

9 This concern was also expressed in Braidotti (1994, 2011), West (1994), and Chanter (1995).

${ }^{10}$ See Amorós (1985), Cavarero (1990), Milan Women's Bookstore Collective (1990), Nagl-Docekal and Pauer-Studer (1990), Moore (1994), Santa Cruz et al. (1994), and Maihofer (1995). 
center stage (Eisenstein and Jardine 1980; Frye 1996). Philosophy departments, however, took a clear and explicit distance from these fashionable trends and closed ranks. Their hostility continued to grow throughout the 1980s as the "theory wars" raged throughout US universities under the combined effects of Reagonomics, neoconservatism, and the rise of the Christian Right. ${ }^{11}$

By 1995, the game was over and the counteroffensive against poststructuralism was well under way (Gallop 1997; Spivak 2003). Nonetheless, the inspirational power of French theories, feminist and otherwise, remained high and affected the most critical and creative minds of that academic generation. Paradoxically enough, poststructuralism did not fare much better in its own home ground, where a wave of so-called new philosophers (Glucksmann 1975; Lévy 1977) turned its back on the philosophical giants of the previous generation (Braidotti 2010). The French academic establishment rejected the very radical thinkers that American academics had embraced. During the Mitterand years, a wave of neonationalist republican pride took over the Left Bank, resulting in a refusal of the cosmopolitan, nomadic, and transnational ideals that had inspired the poststructuralists.

For my generation of feminists, this changing context was dazzling. While we were learning from Foucault, Lyotard, Deleuze, and Derrida about the mutation of capitalism from an industrial to an information society, we could also see all around us the effects of this transformation on intellectual and academic life. Our first encounter with the new and promising business of the import-export of ideas gave us a foretaste of cultural globalization. It resulted in a consolidation of the feminist academic and publishing market, which was to explode into the star culture of the 1980s and become institutionalized by the 1990s. Our careers were to be marked by this new exchange economy of intellectual production, which was and still is centered in the United States. As a consequence, today we know that it is historically but also theoretically impossible to speak of French feminist theory without making implicit reference to this transatlantic nexus and to the fact that these theories essentially belong to the English-speaking world (Oliver 2000; Cavallaro 2003).

This transatlantic disconnection made Les cahiers du Grif all the more important in a period of great historical transition. Collin operated within but also exceeded the boundaries of what was to become known as French feminism. She created a multilayered corpus, free of sectarian belongings and resistant to fashionable beliefs. The independent position taken by her

${ }^{11}$ See Butler and Scott (1992), Neilson (1995), Sprinker (1995), and Williams (1995). 
collective and its broad international readership allowed many Frenchbased feminists to keep some lucidity and to avoid theoretical infighting. We - the graduate students of a field that did not yet formally exist - could see glaring disparities not only in the selection of which French thinkers were being translated but also in the speed of publication of these translations. ${ }^{12}$ We watched the meteoric rise of Derrida and wondered why Deleuze was left behind. ${ }^{13}$ Above all, we admired Collin, who remained independent, avoided the quarrels that tore apart the Parisian women's movement, and steered her own course. Not quite Parisian but no longer Belgian, Collin was the reluctant French feminist.

\section{A life examined}

Françoise Collin was born on April 8, 1928, in Braine-le-Comte, Belgium, and passed away on September 1, 2012, in Saint-Sauveur, Belgium. She attended several Catholic boarding schools and enrolled in philosophy at university. She studied in Paris for two years with Maurice Merleau-Ponty and Jean Hyppolite, and in 1950 she graduated from the Catholic University of Louvain, where she was in the same class as Irigaray and Jacques Taminiaux, whom she was to marry in 1951. They had two children: Laurence in 1955 and Pierre in 1958.

After graduation she became an assistant professor in philosophy at the Facultés Universitaires Saint-Louis in Brussels, from which she was unceremoniously dismissed for "talking too much."14 She never recovered

${ }^{12}$ For instance, Kristeva's work appears quickly in English: About Chinese Women (originally published in 1974) comes out in English in 1977, Desire in Language (originally published in 1969) in 1980, and The Kristeva Reader in 1986 (see, respectively, Kristeva 1977, 1980a, 1986). Cixous is slightly behind, with the 1976 translation of "The Laugh of the Medusa" (originally published in 1975) and the 1986 translation of The Newly Born Woman (cowritten with Catherine Clément and originally published in 1975); The Book of Promethea (originally published in 1983) is translated in 1991, and The Hélène Cixous Reader comes out in 1994 (see Cixous 1976a, 1991, 1994; Cixous and Clément 1986). Irigaray, however, lags behind, with the translations of both Speculum of the Other Woman (originally published in 1974) and This Sex Which Is Not One (originally published in 1977) being published in 1985 and An Ethics of Sexual Difference (originally published in 1984) in 1993, after which the speed picks up (see Irigaray 1985a, 1985b, 1993).

13 The linguistically oriented movement, inspired by Lacan, Derrida, and Barthes, was centered in the Yale school of literary theory; see Johnson (1980, 1998), Felman (1993), and Garber (1997). The pioneers of French feminist theory in the United States were Domna C. Stanton (1980), Alice Jardine (1985), Nancy K. Miller (1986), Naomi Schor (1987), Catharine R. Stimpson (1989), and Joan Wallach Scott (1999). Gayatri Chakravorty Spivak expanded it to postcolonial theory. Interest in Deleuze did not take off until the early 2000s.

14 Thanks to Nadine Plateau for this information. 
from this painful expulsion, and she subsequently taught in a professional school until she moved to Paris. There she was able to teach philosophy at the American University, at Reid Hall, and at the Collège International de Philosophie. ${ }^{15}$ She lectured in all major intellectual and cultural institutions, including the Centre Pompidou. In 1986 and 1988 Collin taught at the Inter-university Centre in Dubrovnik, in the former Yugoslavia, where she mentored younger feminists from the region, including the philosopher Rada Iveković. ${ }^{16}$ Between 2002 and 2011, she lectured and published annually at the Italian summer school on Public Space and the Common World in Lecce, directed by Marisa Forcina. Collin was also a guest professor in 1995 at the Free University in Brussels and in 2005 at the University of Liège. In June 2010 in Paris, she told me that she had been awarded the Légion d'Honneur-the highest distinction granted by the French government-but she never formally accepted it.

By her own admission (see Plateau 2011), Collin's quiet origins in the Belgian countryside had not prepared her for what was to come: a childhood upset by World War II, a youth spent under the spell of the communist dream of a classless society, an academic career broken by the sexist practices of university philosophy departments, the intense encounter with the women's movement - almost a sudden conversion. All this was underscored by her lifelong passion for writing. From her earliest years Collin was acutely aware of the powers of language and fascinated by the magic of words. She talks enthusiastically (Plateau 2011) about borrowing books from the local library and devouring them. The first journal she started was at primary school as an act of protest against the compulsory needlework classes, which she loathed. Of course this subversive act did not go unpunished, and it sealed Collin's relationship of resistance to educational authorities.

Collin's life is marked in direct and permanent ways by the two greatest disasters of the twentieth century: first, World War II and the Holocaust and, then, the horrors of communism. This context makes Collin especially receptive to the work of the most important thinkers in her life: her friend Emmanuel Levinas on Jewish ethics, Maurice Blanchot on death, and Hannah Arendt on both fascism and human rights. A gifted writer and philosopher, she combined the literary and the philosophical. She made her literary debut in 1958 with a collection of poems in the journal Ecrire

15 The Collège International de Philosophie was Mitterand's gift to Paris intellectuals. Cofounded in 1983 by Derrida, Châtelet, Jean-Pierre Faye, and Dominique Lecourt, it aimed to rethink the teaching of philosophy in France and to liberate it from any institutional authority. Attendance of seminars is open and free, just as at the Collège de France.

16 Thanks to Svetlana Slapsak for this information. 
(Collin 1958) and her philosophical breakthrough in 1971 with the publication of her dissertation on Blanchot, which was the first study of this major thinker ever published (Collin 1971).

In 1973, after a trip to the United States, she became, together with Aubenas, a founding editor of Les cahiers du Grif, where she published original translations of leading women writers such as Gertrude Stein, Virginia Woolf, and Marieluise Fleisser. She directed book collections for the publisher Minuit and for the feminist Tierce Press, directed by Françoise Pasquier, who also published Les cabiers $d u$ Grif. Collin was the first to introduce Arendt's thought to France (Collin 1986b, 1988a); she edited the translation of Rabel Varnbagen (Arendt 1986) and applied Arendt to feminist theory in a volume on ontology and politics (Abensour et al. 1989) and later in a book-length study (Collin 1999c).

Collin devoted several edited volumes to women philosophers: first, the French speaking (Collin 1992c) and, then, internationally in collaborative projects with Eleni Varikas and Évelyne Pisier (Kolly 2011) and with Penelope Deutscher on American feminist theories of justice (Collin and Deutscher 2005). ${ }^{17}$ She cowrote, with Forcina, a study on sexual difference in philosophy (Collin and Forcina 1997) and devoted a special issue of Les cahiers $d u$ Grif to the life and work of Kofman, the feminist philosopher (Collin 1997). She was invited by Fraisse to contribute to the twentiethcentury volume of L'histoire des femmes en Occident (see Collin 1992a) and in 2010 was among the founders of the new UNESCO-backed Women Philosophers' Journal (Revue des femmes philosophes).

The versatility of Collin's talents and the wide range of her writings create a number of logistical and methodological problems for the scholarly reception of her work. For one thing, a great deal of Collin's writings are scattered across an unusually large spectrum of different kinds of publications: militant rags and academic journals, popular magazines and encyclopedia entries, edited and coedited volumes from some of the most and many of the least prestigious publishers. Even tracking down all of Collin's editorials, interviews, and single-authored articles within the full collection of Les cabiers du Grif is a daunting task. ${ }^{18}$

17 The issue of Les cahiers du Griffocusing on feminist philosophy in French (Collin 1992c) features Éliane Escoubas, Barbara Cassin, Jeanne Marie Gagnebin, Catherine Chalier, Monique David-Ménard, Monique Schneider, Sarah Kofman, Geneviève Fraisse, Rada Iveković, Myriam Revault d'Allonnes, Françoise Duroux, Françoise Proust, Élisabeth de Fontenay, and Collin. The volume on American feminist theories of justice (Collin and Deutscher 2005) features Susan Moller Okin, Ruth Anna Putnam, Nancy Fraser, Patricia Williams, Annette Baier, Martha Nussbaum, Drucilla Cornell, Catharine MacKinnon, and Judith Butler.

${ }^{18}$ The full archive of the journal is now available online through Persée at http://www .persee.fr/web/revues/home/prescript/revue/grif. 
Second, Collin's exclusion from the university resulted in a kind of exile from academic research institutions. This deprived her of a crucial intergenerational resource: students and $\mathrm{PhD}$ candidates who might have helped her systematize, canonize, and critique her own work. ${ }^{19}$ This labor of love is being undertaken now, and the first challenge is to compile an exhaustive bibliography of all Collin's writings. ${ }^{20}$

This means that the critical, secondary scholarship on Collin is not very rich, especially not in English (see Braidotti 1994, 2010, 2011; Deutscher 2013), although it is better represented in Flemish (Michielsens 2011; Plateau 2011) and Canadian sources (Lamoureux 2010, 2012). What we do have, however, are a number of very enlightening interviews that Collin conducted with leading feminists, in keeping with her stated preference for dialogue as a mode of critical intervention. ${ }^{21}$ In 2008 , Fraisse featured Collin in the series Europe of Ideas on the national radio channel France Culture. ${ }^{22}$ Another interview, with Irene Kaufer, comprises a book-length critical overview of Collin's key ideas and terms and thus counts as both a primary and a secondary source (Kaufer and Collin 2005).

The last, and certainly not the least, of the methodological problems in the reception of Collin's work concerns the issue of languages. Collin's native country, Belgium, is split into two linguistic and administrative areasthe French-speaking Wallonia and the Dutch-speaking Flanders. This is hardly unusual in polylingual Europe, but in this particular case the cultural and economic differences between the two regions are so significant that they engender divergent critical approaches both to feminism and to theoretical practice. The two linguistic communities do not always read each other (the French, in particular, tend not to read the Dutch), although the citizens of Brussels are supposed to be bilingual by law. As a French-speaking Brusselsbased intellectual, Collin was situated in the midst of a rich and culturally diverse environment, Brussels being a free enclave and the third administrative region alongside Wallonia and Flanders. She cumulated the advantages as well as the challenges of belonging to not one but several linguistic

${ }^{19}$ For illuminating accounts of intergenerational relations, see Van der Tuin (2009a, 2009b) and Braidotti (2012).

${ }^{20}$ This task is currently being undertaken by Mara Montanaro at Université Paris Descartes.

${ }^{21}$ See the special issue of Transmission(s) féministe(s), no. 1 (2011), titled "Penser/agir la différence des sexes: Avec et autour de François Collin" (To think/enact sexual difference: With and around François Collin; http://www.sophia.be/index.php/fr/pages/view/1313), especially Collin (2011) and Plateau (2011); see also Rochefort and Haase-Dubosc (2001).

${ }^{22}$ For audio of this interview, see "Entretien entre Geneviève Fraisse et Françoise Collin: La question de la place des femmes en philosophie," Le nouvel observateur, December 5, 2012, http://feministesentousgenres.blogs.nouvelobs.com/les-cahiers-du-grif. 
and cultural communities at once. Having subsequently moved to Paris, Collin added an extra layer of complexity to the dissemination of her work.

When one surveys the scholarship about Collin, therefore, one is confronted by at least two languages: French and Flemish. English scholarship is scarce, but there is a solid contribution from Quebec and Italy, where Collin was a frequent visitor. This means that scholars of Collin need to be nomadic and multilingual, to say the least. The assumption that English is the language of feminist research and scholarship does not do justice to the variety and vitality of autochthonous feminist cultures across many regions of the globe, including Europe. Unless we acknowledge the need to support transnational feminism with a firm commitment to multilingualism, the dominant English-speaking feminist scholarly community erases or confines to the margins a large number of excellent and politically significant nonEnglish-speaking feminists. Collin's work is emblematic of this predicament.

\section{Literary genres}

Although it is tempting to divide Collin's corpus into three neatly separate categories - the philosophical books, the essays in the journal she created and ran for twenty-four years, and the literary texts-I concur with Nadine Plateau (2011) that such a distinction is untenable. There is a profound unity connecting all her work that resides in her engagement with the act and task of writing.

Collin acknowledged the intense but problematic inner cohesion of her oeuvre and stressed that the three main genres she produced-the philosophical, the activist, and the literary texts - are equally important in their respective specificity (Collin 1999a). The first is a more problem-oriented, argumentative mode; the second, an immediate form of intervention into social affairs; and the third - her favorite - a space of pure experimentation. Furthermore, as Deutscher (2013) insightfully points out, part of the inner coherence of Collin's oeuvre comes from the methodical crossovers she performed between different authors. Collin read Blanchot with Arendt (1988c) and confronted them both with Lyotard and Stein: key concepts are lifted and destabilized on purpose, in order to generate a new synergy that resists synthesis and dogmatic fixity. Collin is an antagonistic but loyal reader who clashes with her sources but only in order to complete them and supplement them. Confrontation means neither negation nor correction: Collin's aim is to debunk philosophical sacred cows and treasured theoretical allegiances, especially in a patriarchal system where they are caught in a web of Oedipal power relations. She is the harshest with the ideas she 
loves the best: "Hagiography was as foreign to her disposition as irony was dear" (Deutscher 2013, 20).

I concur with Deutscher (2013) that the literary texts are the moments when Collin gives the best of her talents. The orphaned and self-generating nature of literary writing is what attracts her; it grants her the freedom to roam, to explore, and to invent. A prodigious literary talent, Collin was recognized as a bright light in the world of the nouveau roman by age thirty-two. Her first novel, Le jour fabuleux (The fabulous day), was published to critical acclaim by the leading French publisher Le Seuil (Collin 1960). No mean feat for a girl from Brussels. The issue of Collin's location within the French language as a Belgian is far from accidental: her true home was French, but she settled into an open relationship to it. Collin spoke neither the Parisian argot nor the classical, formal language in which the French have expressed their sense of their own grandeur. She rejected the universalizing force of the great nation's colonial, centralized superego and adopted instead a more humble usage of the French language. French is home, but home is not a familiar place; it is rather the location of multiple differences: a third space. Unlike Édouard Glissant, Collin did not practice or preach creolization but felt that every language was inhabited by the traces of other languages and was a plurality in itself. She roamed freely within and across the polyvalences, ambiguities, and idiosyncrasies of a language she inhabited as her fundamental, vital element but that escaped her almost by definition.

In this respect Collin resembled one of her favorite writers, Stein, who famously went to Paris to be alone with the English language. Collin did something analogous: she went to Paris from her native Belgium to be alone with a French language that did not coincide with the French nation or the annexed empire. Her Belgian tongue is akin to the Turkish, Arabic, Vietnamese, and Hindi languages she crossed in her multicultural neighborhood in Paris. The diversity of that fast-changing global cityscape played a major role in situating and inspiring Collin's writings (Collin 2008).

Collin was set aside from the mainstream: contrary to most Parisian feminists, for instance, she was not opposed to the Islamic veil. She recognized the polysemous value of the act of wearing the veil and refused the hard line set by, among others, Élisabeth Badinter, who saw it as an intrinsic symbol of female oppression. Collin defended her solidarity with Islamic women in the name of her own marginality as a Belgian living in exile in Paris. She was conscious of the importance of diversity and profoundly opposed to the centralized republican spirit of the French Left, which, as Scott (2007) has argued, suppresses all differences. Collin never 
stopped thinking with an accent and siding with the minorities within the larger French-speaking world.

Alone with her own minor variation within a major formation, Collin, self-defined as "l'immigrée blanche" (the white[ned] immigrant; Brodkin 1998; Kaufer and Collin 2005, 78), actualized a nomadic becoming (Braidotti 2011) within the French language. She stressed its regional variations, internal fractures, and street sounds and was quick in exploiting the phonetic and acoustic qualities of each word. Playing with rhythmic alignments, random alliterations, and delirious resonances, her texts often read like a poetry slam avant la lettre.

This style also affected Collin's relationship to other languages. She was a passionate traveler, fascinated by the radical otherness of foreign tongues: she understood many of them but spoke none. English was deliberately excluded from the inner circle of intimacy, playfulness, and complicity that tied Collin almost viscerally to her native French. She displayed a childlike fascination with the English language. In her 1975 account of the US presidential election (Collin 1975), for instance, she just copied down long lists of English proper nouns, street signs, even random recipes for food or cocktails. Transcribing a language she did not speak, as if it were a cryptic code or a mysterious gift from some faraway galaxy, she recognized the formal beauty of the linguistic object but left it out in the cold of a world she could not inhabit: admired but fundamentally unloved.

Strangely enough for a European, Collin was monolingual, but only because she spoke several variations of French and never stopped perfecting her sensitivity to the nuances of this language. Her monolingualism, therefore, was born of overabundance, not of lack. She never allowed her language to grow tired and lose creative tension. Like all writers of genius, Collin reinvented her language with each new writing project: it remained forever other.

\section{Intransitive writing}

Like Beauvoir and other women of that generation, Collin writes the way most of us breathe: it is an intransitive gesture, an end in itself. Writing is Collin's mode of inscription into life. Before becoming a published writer, she already was a graphomaniac. ${ }^{23}$

The idea of the intransitive nature of writing pertains to one of the axioms of structuralism, namely, the primacy of language as the constitutive

${ }^{23}$ I use this term to describe people, mostly women, for whom writing is a life-giving mediating factor. 
structure of human subjectivity. ${ }^{24}$ In this perspective, language is not just (or even) an instrument of communication but rather an ontological site of the constitution of our shared humanity (Braidotti and Schrift 2010; Braidotti 2011). Language as the mediator between the self and the natural and social environments functions as a third party that separates human subjects from the conditions that engendered them in the first place, namely, the maternal body. In a patriarchal system, the task of splitting the native dyad is fulfilled by the father. Therefore, the phallic law of the father is not only the master code of language but also the key symbolic rule in our social system. ${ }^{25}$ Call it second nature. Contrary to Beauvoir and JeanPaul Sartre, who inhabited language as a tool of critical analysis and rational political intervention, Collin felt inhabited by it as an other within. In this respect she was close to the sensibility of poststructuralist thinkers like Derrida (1976) and Kristeva (1991).

Collin was acutely aware of the violence - both physical and symbolicthat this phallic law enacts against women. Institutionalized in the exchange of women in patriarchal kinship systems, it links nativity to expropriation. This results in the objectification and subsequent exclusion of women from the social contract. Their disqualification is so profound an injustice that it literally leaves you speechless. Not only does it defy legal redress, it begs for an adequate language in which to express the sorrow and anger that infuse it.

This takes us back to the intransitive nature of writing. If language is both an ontological precondition and an ethical interpellation, then the writer's obligation is to remain loyal to this fundamental premise and to labor to share it with readers. As Blanchot argues, writing is the visualization of ethical relationality. We are faced here with a seemingly contradictory statement: that language, as an ontological a priori, is external to the bound self but is also a constant presence at the heart of the self, thereby inscribing the relation to others as the defining feature of our common humanity. Writing as the deployment of its own analytic preconditions is intransitive in the sense that it has no object other than itself, yet insofar as it is always tied to others, it already involves quite a crowd. Writing for Collin is the expression of the vital and productive bond that connects us to the multiple environments we inhabit, and thus it is always and already outward bound; it belongs to the world. This kind of public writingembedded and embodied-is integral to the feminist project.

\footnotetext{
${ }^{24}$ See Deleuze (1973), Coward and Ellis (1977), Descombes (1980), and Ingram (2010).

25 The latter is also known as the logocentric system for Lacan and the phallologocentric system for Derrida.
} 
From Olympe de Gouges's universal Declaration of the Rights of Women to the lyrics of Pussy Riot's songs, women have written their protests in letters of ink, fire, and at times even blood. ${ }^{26}$ They have written on paper, stone walls, sand, and often on their own bodies. This is writing as "maps of intensities" (Deleuze and Parnet 1977, 38; see also Braidotti 2006). It is writing as coterminous with acting in the world in order to empower affirmative becomings on the part of social subjects who have been historically deprived of the right to speak (Braidotti 2011). It is writing for the illiterates, the marginal, the ones left behind. It is akin to a visceral scream of rebellion against the centralized master code of sovereign power.

Feminist writing is writing-against in order to liberate other forces, potentials, and political dreams at the heart of both those who do the writing and the readers who are their intended recipients. But being against does not make it negative, although it is definitely oppositional. Writing, as Collin brilliantly demonstrates, is the exploration of unlimited new possibilities for action, representation, and sheer emotional and intellectual pleasure. Intransitive writing as a vehicle of intensity is always affirmative; it is a generous act of intervention on our common world.

\section{The m/other}

In a poignant text, Le rendez-pous, written in 1988 to commemorate her mother's death, Collin reaches one of the highest points of her literary maturity (Collin 1988b). Minimalist in tone and style, this text-lying between the poetic, the fictional, and the autobiographical-avoids all lexical exuberance to get to the core of the experience of loss, pain, and mourning. Framed in an impersonal syntax devoid of reference to the unitary identity of the writer, the narrative deploys a complex emotional range-including gratitude, regret, love, and resentment-along two basic registers. First there is the other: "you" $(t u)$, the mother who is both the object of the daughter's lifelong dependence and the point of resistance to her endless requests for love. And then there is "she" (elle), the third-person singular who takes the place of the speaking subject of the author herself. The stark, ascetic tone allows Collin to inject rhythmic emotional variations in the text, playing with intensity while avoiding emotional excess.

At center stage is the ancestral, visceral, and somehow (at least for Françoise) unresolvable knot of the mother-daughter relationship. In a literary balancing act, Collin succeeds in rendering the vitality of that rela-

${ }^{26}$ De Gouges died under the guillotine, and the members of Pussy Riot are serving twoyear jail terms in the Russian Federation for blasphemy and insurrection. 
tionship, even and especially in its negative aspects. Infinitely demanding (Critchley 2007), the bond between the two is inexhaustible and all encompassing. Source of life and threshold onto death, the mother's body emerges from this important text as incommensurable - she is the eternal other who both connects to and screens the daughter from the elusive figure of the father. One does not need psychoanalytic theory to get the point: being all of woman born (Rich 1976), we know that one does not stir without the other (Irigaray 1981).

Collin relies and somehow builds on this common world of women, for whom the mother-daughter dyad is an all-too-familiar existential, symbolic, and social destiny. The position of highly talented, creative women is especially delicate in this configuration. In honoring the bond with her mother and showing up on time for what will turn out to be the last day of her life, the daughter acknowledges both cognitively and affectively their interconnection. As she surveys the life of the $\mathrm{m} /$ other, Collin also produces a lucid genealogy of her own creativity and how it is rooted in this complicated relationship. The space between them is a generative force that connects nativity to what Collin calls "fecundity" (Kaufer and Collin $2005,109)$, but it is not free of pain. Their relationship is an ongoing process, flawed and hence real: it consists of triumphs of loving care but also of dismal failures. Collin is relentless in accounting for the shortcomings that consolidate but also mar their interaction. That lucidity expresses her respect and, ultimately, her compassion.

The mother's body becomes text; her life is a narrative that weaves the basic pattern of the daughter's existence. She will have been a mother made of words, of language - a storyteller. The mother tongue resonates in the daughter's words - she is the body of language. Significantly, Collin does not entrust these complex ideas to philosophical thought. She chooses not to theorize the feminine specificity of the mother-daughter bond, nor does she wax lyrical about the woman-to-woman eroticized space. Collin is far too aware of the incisive, at times painful, singularity of her mother to believe in an originary fluidity of boundaries between mothers and daughters. If anything, the mother figure comes into full, sharp focus in her texts with merciless lucidity: there is nothing cosmic or cryptomystical about her. In this respect she differs considerably from the bulk of her contemporaries, notably the écriture féminine movement that iconized the motherdaughter bond as the symbol of a foundational female homosexual libidinal economy. This position is defended, for instance, by what I define as the left-wing Lacanian feminists, namely, Jeanne Hyvrard (1976), Irigaray (1976), and Cixous (1991), but also by the right-wing Lacanian feminists led by Kristeva (1980b). 
What comes to the fore in Collin's work is the primacy of the relation with and hence the uniqueness of the mother figure but also her aloneness, even and especially in face of her daughter. Together alone, aware of the ties that bind them yet separated and distinct from each other, Collin's mother and daughter are two morally mature adults who have accepted the terms and conditions of their mutual interdependence and their respective failings. The ethics of otherness begins right here, for Collin, in the recognition of both catastrophes and successes, pain and loving presence, in the awareness that one is never fully accomplished, never a perfect unit, finite and in control. We are rather not-ones, dynamic and mutable, forever seeking admission to that last chamber, trying not to miss the last rendezvous with the ones we love, or more precisely with their death. As a writer, Collin paces up and down the corridor outside that dark room, trying to stay awake and not miss the hour. She thus expresses both an awareness of her limitations and a yearning for ethical care-her love-in the only way allowed to us mortals: by simply being there, enduring the pain of the other, witnessing the agony without cracking or turning away. She is writing as a witness, not out of anguish but with confidence in the necessity of the ethical relation with the $\mathrm{m} /$ other, without delusions of perfection or of moral grandeur. Here, we are at the antipodes of Irigaray's feminine symbolic but also of Carol Gilligan's (1982) moral case.

Collin's feminist ethics was based not on metaphysical femininity but rather on political praxis as the key factor in transformation. The women's movement was for her a project of alternative feminist sociality, expressing a shared ethical aspiration to justice. Maybe this attitude also affects Collin's own relationship to the many spiritual daughters, students, and fans she left behind. She was not remotely maternal in any conventional sense of the term. On the contrary, she was an exacting teacher, demanding and rigorous with her junior collaborators. All texts - original writings or translations-were subjected to intense and constant editing and corrections, which delayed and at times blocked entire projects. But in some ways it did not matter because for Françoise the process was more important than the end product. She had insight into people, and especially younger women, but her support for them took the form of unfailing, albeit ironic, watchfulness. Deutscher sums it up brilliantly: "The keen, lucid eye she brought to the life of other women was Collin's form of solidarity with them" $(2013,20)$. When I invited her to the inaugural lecture of my women's studies professorship in Utrecht in 1989, she was both warm and slightly skeptical about the academic gowns and all the pomp and circumstance. Her gift to me was a signed copy of the book Le rendez-pous, and the 
dedication, written in her flowing handwriting, just said: "For Rosi, with confidence in your future. Françoise.” The rest is silence.

\section{Difference, differing, differend}

Collin's feminism is informed by the same principles as her writing practice. Under the influence of Blanchot, Levinas, and Lyotard, Collin built a conceptually sophisticated feminist theory, positioning difference as a foundational category but stressing its process-like nature. Difference is not caught in the lethal dialectical binary that freezes it in a hierarchical scale of relations, but rather it is the process of constant differing that is internal to all subjects and concepts. In this respect Collin is closer to Derrida, on difference as différance - the perpetual space-time interval not only between entities but also within them-than to Irigaray's firm belief in women's essential difference (Collin 1971, 1992c).

Difference is originary, that is to say internal to the self and to self-other relations, as shown by the intransitive nature of language and the complexity of the mother-daughter bond. It is neither an ontological given nor an epistemological construct but rather an ethical relation to others. Adding Arendt to this equation, Collin (1986a) argues that to be someone is to be a dynamic plurality. This constitutive multiplicity does not deny the uniqueness of the individual but grounds it in fundamental forms of relation. It also requires sensitivity to the nuances of complex life events and a suspension of belief in final truths. Ultimately, Collin's vision of the subject rests on the belief that one is never fully completed, which also means that a feminist is not-one at heart and that this inner complexity is her strength. Difference that is constitutively not-one defines the subject as the freedom to differ, even from itself.

The political implications are clear: if difference is not a concept, but rather a verb, it produces praxis as a way of modulating singular variations within a common world. Collin's political practice is grounded in an awareness of the structural presence of disaster at the heart of the human subject. Ontologically, the disaster resides in the ubiquity of death; historically, in events like the Holocaust and the gulag. As I suggested earlier, Collin was haunted, both generationally and philosophically, by the specter of failure and injustice. In a letter she wrote to me in 1990, she said, "I think I have a resolutely pessimistic view of the human being, women included. I am conscious of a wrong and a misunderstanding that can only be sustained and surmounted by constant hard work. There are some spaces that miraculously offer escape from this general rule, but the feminine space is not one of 
them." ${ }^{27}$ Collin kept this somber disposition in check by cultivating two affirmative qualities: a quick sense of the absurd and a deep gratitude for human kindness.

The acute consciousness of injustice, pain, and loss constitutes the "differend" (Lyotard 1983), which is not essentialist difference but structural flaw and damage at the heart of the subject. As such it is not contingent but fundamental and thus irreparable. Collin urges all political activists to recognize this dimension and suspend the quest for legal and financial compensation, to focus instead on transformative ethics. Feminism is the generative response to these wrongs, as it addresses a fundamental transhistorical and cross-cultural injustice: the "sexual differend" (Collin 1999b).

This approach acquires both analytic and normative dimensions. Analytically, it produces a method to assess the status and position of women in society as well as in theoretical practice. Normatively, it defines the parameters for her vision of feminism as an ethical philosophy of human liberation, as well as a political practice aimed at bettering the social status of women and repairing the social and symbolic violence of patriarchy. Because of the incommensurable nature of the injustice suffered by women (the symbolic feminicide at the core of the sexual differend), an extra ethical and political effort is needed by both sexes to reconstruct their relationship and transform the common, public sphere. Both aims-the analytic and the normative-converge in Collin's lifelong commitment to thinking through and with women as one of the main axes of difference but by no means as the only or primary one.

The challenge for feminist thinkers is to support the ongoing struggle for rights while remaining aware that the ontological damage is such that "it exceeds justice" (Deutscher 2013, 21). What is at stake in feminism is the plural empowerment (potentia) of all women, not their access to the monological mechanisms of power. Collin resists the reversal of power relations that would turn the former victims into new oppressors, for fear that it might end up perpetuating the forms of violence and inhumanity that feminism is committed to fighting. For Collin, feminists should stay loyal to a mild form of nonpower (im-pouvoir) and refuse to join "the community of the winners" (Deutscher 2013,21). The feminist is not one ideologically bound political subject with a clearly defined historical mission but rather a work in progress situated between two necessary but distinct poles: on the one hand, the quest for justice, and on the other, the yearning for freedom. These two aims may be complementary, but they

${ }^{27}$ Letter from Collin to the author, December 7, 1990, on file with the author. 
are also potentially contradictory in that the former requires an awareness of oppression as well as the desire to overthrow it while the latter is open ended and almost structurally undefined. Collin's work is a constant attempt to bridge the gap or at least strike a balance between the two.

Collin stressed the transformative character of feminist thought and practice. Passionate faith in the creative nature of feminist ethics and knowledge production, however, also bred suspicion toward institutionalized curricula in women's, gender, and feminist studies. The feminist thinker was for Collin a public intellectual, not a specialized researcher in a recognizable academic field. Believing in the women's movement as an original laboratory of ideas, Collin (2011) resisted the transition from insurrection to institutions: the university as a whole and academic feminists in particular were indebted to the many militant women who, without being intellectuals themselves, contributed greatly to the collective task of developing new ideas and methodologies and alternative ways of transmitting them. In order to harmonize the interaction between activists and intellectuals, Collin labored to provide a public forum through the autonomous venue of Les cahiers du Grif. This anti-institutional politics did not prevent Collin and her team, however, from organizing those independent seminars and workshops that we eagerly attended as graduate students. She was also responsible for the first European survey of women's studies courses and activities, both in the university and in autonomous women's centers. This resulted in the first European conference on feminist research in 1989, in Brussels, with support from the European Commission. ${ }^{28}$

A pioneer in feminist philosophy, Collin did not aim, however, to set up a fixed tradition or an institutionalized canon. She had adopted from René Char the definition of feminism as an "inheritance without a will" (Collin 1986b). At no point in her complex intellectual project did Collin aspire to imitate the male philosophical stance, which consists in emphasizing transcendence and a disembodied practice of philosophy. The supposed neutrality of the knowing subject betrays for Collin the highest form of self-interest and self-referentiality: the male separatist practice of philosophy. It expresses the homosocial nature of philosophical thought, which is linked both to male homoeroticism and to the ancestral exclusion of women from the public sphere, including the philosophical agora. Philosophy is a sort of church, and it does not ordain women (Collin 1993).

28 The GRACE databank project, coordinated by Veronique Degraef, also began under the auspices of Les cabiers $d u$ Grif. This project led to the establishment of Sophia, the Belgian Coordinating Network of Feminist Studies, which is alive and well today. 
These asymmetrical power relations perpetuate the sexual differend and result in a woman's truth seldom being recognized or acquiring universal value. This disqualification is often internalized by women themselves, who lack the confidence to assert their own ways of knowing.

Collin extended the same suspicion of rationality to contemporary science and notably to reproductive technologies, fearing they may threaten the human condition and strike out at women with particular violence (Collin 1999c). The main thrust of Collin's work on feminist philosophy is consequently metamethodological (Collin 1992b): she focused on the underrepresentation of women both in philosophy departments and in the curriculum of the history of philosophy. ${ }^{29}$ She highlighted the contribution of real-life women to the discipline and investigated the construction of the feminine within it, criticizing male philosophers' lack of generosity toward their female colleagues.

Equality was a worthy cause for Collin, so long as feminists avoid amalgamation into the masculine model of abstract, rationally detached subjectivity (Bordo 1986). She asked over and over again: "Is feminism the becoming-men of women or the becoming-other of both men and women?" (Kaufer and Collin 2005, 16). In this regard, Collin is in agreement with her peer Irigaray, who argued that heterosexuality has not been implemented as an equal practice in the Western world, where only one sex-the masculine - counts as subject and constructs the world in his image, including a gender system indexed according to his needs and desires. While endorsing this analysis, Collin was skeptical of the notion that subjectivity is somehow the monopoly of the masculine, reducing women to a lesser ontological status. She responded by stressing instead the constitutive incompleteness of all subjects. Beyond the differend, feminism is a generative but also pragmatic praxis aimed at the reconstruction of a common world based on respecting the irreducible plurality of every single individual.

Collin extended the same faith in the generative powers of feminism to the work of women artists in the visual arts, painting, and cinema. As Plateau (2011) has pointed out, she was as sensitive to their mission as she was to the work of women writers and philosophers. All artwork by women is feminist insofar as it combines critique with creativity. Art is based on openness and risk; it takes nothing for granted and relies only on the process. Transformative and rebellious, inspired and oppositional, feminist art is another form of structured intensity: it sustains the project of creating new beginnings, of giving birth to possible worlds.

\footnotetext{
${ }^{29}$ For a contemporary account, see Butler and Braidotti (2010).
} 


\section{Epilogue}

Françoise Collin marked my generation's intellectual life and taught me a lot about the purpose of feminist philosophy, the political passions of activism, the perennial challenge of writing, and the exhilaration of mapping uncharted theoretical territories. Mindful of the sober portrait Collin produced of her dead mother in Le rendez-pous, I want to echo her words and say that, for me, Collin, was a master of embodied language. And her language-scape was European, not oriented toward English. She came with a narrative baggage that remains unequaled in my experience: the staggering intimacy with the French language, which she wrote like a Belgian migrant, without pretensions of mastery. Uncompromising in her convictions, she remained open to a world she inhabited humbly, as a passerby. Erudite, but never condescending, she came with a repertoire of characters who inflamed our imagination: Stein (a passion she shared with Stimpson) and Arendt, Blanchot, and Levinas, but also her next-door neighbor and random people met in the streets of Paris. An ancient soul, Collin belonged to the centuries-long, painful history of women philosophers who were rejected by their discipline. She resonated with the fervor of feminist revolutionaries, from Lysistrata to Kate Millett, but was also attuned to artists like Chantal Ackerman, Alina Szapocznikow, and Marguerite Duras. She was a charismatic activist, a brilliant thinker, an amazing writer.

A radical who preferred the margins, she was quick in her insights, deep in her perception, impatient with protocols and conventions, and firmly opposed to fashionable ideas. A rebel at heart, but profoundly loyal to the life of the mind, Collin was fully committed to the pursuit of critical thinking. A daydreamer to boot (once she missed a connecting flight during a stopover in Dubai because she just strolled endlessly through the enchanted world of the airport shopping mall) Collin was also lucid to the point of cruelty. Unfailing in her role as a critical witness to her times, fellow traveler and coworker in the task of making women's difference into a positive force in the common world, ironic and self-deprecating, she would hate being claimed as an ancestor, and, perhaps because of this rejection of the trappings of maternal thinking, Collin remains a generative force for all who read her. Alone and one of a kind, Françoise Collin endures.

Centre for the Humanities

Utrecht University 


\section{References}

Abensour, Miguel, Christine Buci-Glucksmann, Barbara Cassin, and Françoise Collin, eds. 1989. Ontologie et politique: Actes du colloque Hannah Arendt [Ontology and politics: Hannah Arendt conference proceedings]. Paris: Tierce. Amorós, Celia. 1985. Hacia una critica de la razón patriarcal [Toward a critique of patriarchal reason]. Barcelona: Anthropos.

Arendt, Hannah. 1986. Rahel Varnhagen: La vie d'une Juive allemande à l'époque du Romantisme [The life of a German Jew in the age of Romanticism]. Ed. Françoise Collin. Trans. Henri Plard. Paris: Tierce.

Bordo, Susan. 1986. "The Cartesian Masculinization of Thought." Signs: Journal of Women in Culture and Society $11(3): 439-56$.

Braidotti, Rosi. 1994. "Toward a New Nomadism: Feminist Deleuzian Tracks; or, Metaphysics and Metabolism." In Gilles Deleuze and the Theater of Philosophy, ed. Constantin V. Boundas and Dorothea Olkowski, 157-86. New York: Routledge.

2006. Transpositions: On Nomadic Ethics. Cambridge: Polity.

2010. "Feminist Philosophy: Coming of Age." In After Poststructuralism: Transitions and Transformations, ed. Rosi Braidotti, 211-45. Vol. 7 of The History of Continental Philosophy, ed. Alan D. Schrift. Durham: Acumen.

- 2011. Nomadic Subjects: Embodiment and Sexual Difference in Contemporary Feminist Theory. 2nd ed. New York: Columbia University Press.

2012. "Preface: The Society of Undutiful Daughters." In Undutiful Daughters: New Directions in Feminist Thought and Practice, ed. Henriette Gunkel, Chrysanthi Nigianni, and Fanny Söderbäck, ix-xix. New York: Macmillan.

Braidotti, Rosi, and Alan D. Schrift. 2010. "Psychoanalysis and Desire." In Poststructuralism and Critical Theory's Second Generation, ed. Alan D. Schrift, 31136. Vol. 6 of The History of Continental Philosophy, ed. Alan D. Schrift. Durham: Acumen.

Braidotti, Rosi, and Jane Weinstock. 1980. "Herstory as Recourse." Hecate 4(2): $25-28$.

Brau, Jacqueline. 2007. “Au coeur du feminism des années 1970: Le Groupe de recherche et d'information féministes (GRIF) 1972-78" [At the heart of feminism in the 1970s: The feminist research and information group (GRIF) 197278]. Sextant, nos. 23-24: 227-52.

Brodkin, Karen. 1998. How Jews Became White Folks and What That Says about Race in America. New Brunswick, NJ: Rutgers University Press.

Brossard, Nicole. 1977. "L'amère" [The bitter]. Les cabiers du Grif, nos. 17-18: 29-33.

Butler, Judith, and Rosi Braidotti. 2010. "Out of Bounds: Philosophy in an Age of Transition." In After Poststructuralism: Transitions and Transformations, ed. Rosi Braidotti, 307-35. Vol. 7 of The History of Continental Philosophy, ed. Alan D. Schrift. Durham: Acumen. 
Butler, Judith, and Joan Scott, eds. 1992. Feminists Theorize the Political. New York: Routledge.

Cavallaro, Dani. 2003. French Feminist Theory: An Introduction. London: Continuum.

Cavarero, Adriana. 1990. Nonostante Platone: Figure femminili nella filosofia antica [In spite of Plato: Female figures in ancient philosophy]. Rome: Editori Riuniti.

Chanter, Tina. 1995. Ethics of Eros: Irigaray's Re-writing of the Philosophers. New York: Routledge.

Châtelet, François. 1970. La philosophie des professeurs [The professors' philosophy]. Paris: Grasset.

Cixous, Hélène. 1976a. "The Laugh of the Medusa." Trans. Keith Cohen and Paula Cohen. Signs 1(4):875-93.

1976b. "Le sexe ou la tête" [Your sex or your head]. Les cahiers du Grif, no. 13: 5-15.

. 1991. The Book of Promethea. Trans. Betsy Wing. Lincoln: University of Nebraska Press.

1994. The Hélène Cixous Reader. Ed. Susan Sellers. New York: Routledge.

Cixous, Hélène, and Catherine Clément. 1986. The Newly Born Woman. Trans. Betsy Wing. Manchester: Manchester University Press.

Collin, Françoise. 1958. "Poèmes." Ecrire, no. 6.

- 1960. Le jour fabuleux [The fabulous day]. Paris: Éditions du Seuil.

1971. Maurice Blanchot et la question de l'écriture [Maurice Blanchot and the question of writing]. Paris: Gallimard.

—. 1975. 331W20: Lection du president [331W20: Presidential election]. Brussels: Transédition.

— Cinema gaze violence]. Special issue, Les cahiers du Grif, no. 25.

, ed. 1986a. "Hannah Arendt." Special issue, Les cabiers du Grif, no. 33.

1986b. "Un héritage sans testament" [Inheritance without a will]. Les cabiers du Grif, no. 34: 81-92. no. 4 .

, ed. 1988a. "Hannah Arendt." Special issue, Les cahiers de philosophie 37,

1988b. Le rendez-pous. Paris: Tierce.

1988c. "Poétique et Politique: De Maurice Blanchot à Hannah Arendt."

Le cahiers du College international de philosophie, no. 5: 143-48.

1992a. "Différence et différend: La question des femmes en philosophie"

[Difference and differend: The question of women and philosophy]. In Histoire des femmes en Occident [Women's history in the Western world], vol. 5, Le XXe siècle [The twentieth century], ed. Françoise Thébaud, 265-66. Paris: Plon.

- 1992b. Le sexe des sciences: Les femmes en plus [The sex of science: Add women and stir]. Paris: Editions Autrement.

— ed. 1992c. "Provenances de la pensée: Femmes/philosophie" [Sources of thought: Women/philosophy]. Special issue, Les cahiers du Grif, no. 46. 
1993. "Le philosophe travesti ou le féminin sans les femmes" [The philosopher in disguise; or, The feminine without women]. Futur antérieur [Future perfect] (April): 205-35.

, ed. 1997. "Sarah Kofman." Special issue, ser. 3, Les cahiers du Grif.

1999a. Je partirais d'un mot: Le champ symbolique [To begin with one word: The symbolic field]. Villenave d'Ornon: Éditions Fus-Art.

1999b. Le différend des sexes: De Platon à la parité [The sexual differend: From Plato to parity]. Nantes: Editions Pleins Feux.

1999c. L'homme est-il devenu superflu? Hannah Arendt [Has man become superfluous? On Hannah Arendt]. Paris: Odile Jacob.

- 2008. On dirait une ville: Suivi de chronique d'un été [It could be a city: Chronicles of a summer]. Paris: des Femmes-Antoinette Fouque.

2011. "Penser/agir la différence des sexes: Entre insurrection et institution" [To think/enact sexual difference: Between insurrection and institution]. Transmission(s) féministe(s), no. 1: 6-15. http://www.sophia.be/app/webroot /files/Collin-penseragirladifferencedessexes-FrancoiseCollin.pdf.

Collin, Françoise, and Penelope Deutscher, eds. 2005. Repenser le politique: L'apport du féminisme [Rethinking the political: The contribution of feminism]. Paris: Éditions Campagne première.

Collin, Françoise, and Marisa Forcina. 1997. La differenza dei sessi nella filosofia: Nodi teorici e problemi politici [Sexual difference in philosophy: Theoretical issues and political problems]. Lecce: Millella.

Coward, Rosalind, and John Ellis. 1977. Language and Materialism: Developments in Semiology and the Theory of the Subject. London: Routledge \& Kegan Paul.

Critchley, Simon. 2007. Infinitely Demanding: Ethics of Commitment, Politics of Resistance. London: Verso.

Deleuze, Gilles. 1968. Différence et répétition [Difference and repetition]. Paris: Presses Universitaires de France.

1973. "Á quoi reconnait-on le structuralisme?” [How can we recognize poststructuralism?]. In Histoire de la philosophie, idées, doctrines [History of philosophy, ideas, doctrines], vol. 8, Le XXe siècle [The twentieth century], ed. François Châtelet, 299-335. Paris: Hachette.

Deleuze, Gilles, and Claire Parnet. 1977. Dialogues. Paris: Flammarion.

Delphy, Christine. 1975. "Pour un féminisme matérialiste" [For a materialist feminism] L'arc 61 (April): 61-67.

1984. Close to Home: A Materialist Analysis of Women's Oppression. Trans. and ed. Diana Leonard. Amherst: University of Massachusetts Press.

$\rightarrow$. 1995. "The Invention of French Feminism: An Essential Move." Yale French Studies, no. 87: 190-221.

Derrida, Jacques. 1976. Of Grammatology. Trans. Gayatri Chakravorty Spivak. Baltimore: Johns Hopkins University Press.

Descombes, Vincent. 1980. Modern French Philosophy. Trans. L. Scott-Fox and J. M. Harding. Cambridge: Cambridge University Press.

Deutscher, Penelope. 2013. "An Introduction to Françoise Collin's 'Name of the Father.'” Radical Philosophy, no. 178: 19-21. 
D'Hooghe, Vanessa. 2011. "Un historique des Cabiers du Grif" [A history of Cabiers du Grif]. Transmission(s) féministe(s), no. 1: 23-34. http://www .sophia.be/app/webroot/files/Collin\%20-\%20Historique\%20historiek\%20 Cahiers\%20du\%20Grif\%20-\%20Vanessa\%20DHooghe.pdf.

Duchen, Claire. 1986. Feminism in France: From May '68 to Mitterand. London: Routledge \& Kegan Paul.

Eisenstein, Hester, and Alice Jardine, eds. 1980. The Future of Difference. New York: Barnard College Women's Center.

Felman, Shoshana. 1993. What Does a Woman Want? Reading and Sexual Difference. Baltimore: Johns Hopkins University Press.

Fouque, Antoinette. 1982. "Féminisme et/ou mouvement des femmes." In Images de femmes: Mythe et histoire, ed. Martine de Gaudemar, 177-87. Paris: Centre détudes feminines de l'Úniversité de Provence.

Frye, Marilyn. 1996. "The Necessity of Differences: Constructing a Positive Category of Women." Signs 21(4):991-1010.

Gallop, Jane. 1997. Feminist Accused of Sexual Harassment. Durham, NC: Duke University Press.

Garber, Marjorie. 1997. Vested Interests: Cross-Dressing and Cultural Anxiety. Oxford: Taylor \& Francis.

Giannini Belotti, Elena. 1975. "La violence contre le nouveau-nè" [Violence against the newly born]. Trans. Lina Balestrière. Les cahiers du Grif, nos. 9-10: 41-45.

Gilligan, Carol. 1982. In a Different Voice: Psychological Theory and Women's Development. Cambridge, MA: Harvard University Press.

Glucksmann, André. 1975. La cuisinière et le mangeur d'hommes: Essai sur les rapports entre l'état, le marxisme et les camps de concentration [The cook and the man-eater: Essays on the relationship between the state, Marxism, and the concentration camps]. Paris: Éditions du Seuil.

$\rightarrow$ Héritier, Françoise. 1984. "Le sang du guerrier et le sang des femmes: Notes anthropologiques sur le rapport des sexes" [The warrior's blood and women's blood: Anthropological notes on the relationship between the sexes]. Les cabiers du Grif, no. 29: 7-21.

$\rightarrow$ Huston, Nancy. 1976a. "Conjurations." Les cabiers du Grif, no. 13: 29-30.

. 1976b. "S'en prendre à la lettre" [Taking it literally]. Les cabiers du Grif, no. 12: 18-19.

1983a. "C'est louche" [It's dodgy]. Les cahiers du Grif, no. 28: 69-74.

1983b. "J'ai envie de faire l'amère" [I feel like bitter love]. Les cabiers $d u$ Grif, no. 26: 9-13.

Hyvrard, Jeanne. 1976. Mère la mort [Mother death]. Paris: Minuit.

Ingram, David, ed. 2010. Critical Theory to Structuralism: Philosophy, Politics, and the Human Sciences. Vol. 5 of The History of Continental Philosophy, ed. Alan D. Schrift. Durham: Acumen.

Irigaray, Luce. 1974a. "Ce sexe qui n'en est pas un" [This sex which is not one]. Les cahiers du Grif, no. 5: 54-58.

_. 1974b. "Psychanalyse et sexualité féminine" [Psychoanalysis and female sexuality]. Les cahiers du Grif, no. 3: 51-65. 
1976. "Quand nos lèvres se parlent" [When our lips speak together]. Les cahiers du Grif, no. 12: 23-28.

. 1981. "And the One Doesn't Stir without the Other." Trans. Hélène Vivienne Wenzel. Signs 7(1):60-67.

- 1985a. Speculum of the Other Woman. Trans. Gillian C. Gill. Ithaca, NY: Cornell University Press.

- 1985b. This Sex Which Is Not One. Trans. Catherine Porter with Carolyn Burke. Ithaca, NY: Cornell University Press.

1993. An Ethics of Sexual Difference. Trans. Carolyn Burke and Gillian C. Gill. Ithaca, NY: Cornell University Press.

Jardine, Alice A. 1985. Gynesis: Configurations of Woman and Modernity. Ithaca, NY: Cornell University Press.

Johnson, Barbara. 1980. The Critical Difference: Essays in the Contemporary Rhetoric of Reading. Baltimore: Johns Hopkins University Press.

- 1998. The Feminist Difference: Literature, Psychoanalysis, Race, and Gender. Cambridge, MA: Harvard University Press.

Kaufer, Irène, and Françoise Collin. 2005. Parcours féministes: Entretiens avec Françoise Collin [Feminist itineraries: Interviews with Françoise Collin]. Brussels: Labor.

Kolly, Bérengère, ed. 2011. Françoise Collin, Évelyne Pisier, and Eleni Varikas: Les femmes de Platon à Derrida; Anthologie critique [Françoise Collin, Évelyne Pisier, and Eleni Varikas: Women from Plato to Derrida; A critical anthology]. 2nd ed. Paris: Dalloz.

Kristeva, Julia. 1975. "Unes femmes" [Some women]. Interview by Eliane Boucquey. Les cahiers du Grif, no. 7: 22-27.

- 1977. About Chinese Women. Trans. Anita Barrows. London: Boyars.

1980a. Desire in Language: A Semiotic Approach to Literature and Art. Trans. Thomas Gora, Alice Jardine, and Leon S. Roudiez. New York: Columbia University Press.

- 1980b. Pouvoirs de l'horreur: Essai sur l'abjection [Powers of horror: An essay on abjection]. Paris: Éditions du Seuil.

- 1984. Revolution in Poetic Language. Trans. Margaret Waller. New York: Columbia University Press.

- 1986. The Kristeva Reader. Ed. Toril Moi. New York: Columbia University Press.

—. 1991. Strangers to Ourselves. Trans. Leon S. Roudiez. New York: Colombia University Press.

Lamoureux, Diana. 2010. Pensées rebelles [Rebellious thoughts]. Montreal: Éditions Rémue-ménage.

_. 2012. "Françoise Collin ou le souci de la pluralité" [Françoise Collin or the concern of the plurality]. Le nouvel observateur, September 11. http:// feministesentousgenres.blogs.nouvelobs.com/archive/2012/09/11/francoise -collin-par-diane-lamoureux.html.

Lévy, Bernard-Henri. 1977. La barbarie à visage humain [Barbarism with a human face]. Paris: Grasset. 
Lyotard, Jean-François. 1979. La condition postmoderne: Rapport sur le savoir [The postmodern condition: A report on knowledge]. Paris: Minuit. - 1983. Le différend. Paris: Minuit.

Macciocchi, Maria Antonietta. 1979. Les femmes et leurs maitres [Women and their masters]. Paris: Christian Bourgeois.

Maihofer, Andrea. 1995. Geschlecht als Existenzweise: Macht, Moral, Recht und Geschlechterdifferenz [Gender as a mode of existence: Power, morality, law and gender difference]. Frankfurt: Helmer.

Marini, Marcelle. 1977. Territoires du féminin: Avec Marguerite Duras [Territories of the feminine: With Marguerite Duras]. Paris: Minuit.

Marks, Elaine, and Isabelle de Courtivron. 1980. New French Feminisms: An Anthology. Amherst: University of Massachusetts Press.

Michielsens, Magda. 2011. "Een weerzien van Françoise Collin" [Françoise Collin revisited]. Transmission (s) féministe(s), no. 1: 16-22. http://www.sophia.be/app /webroot/files/Collin-een\%20weerzienvanFrancoiseCollin-MagdaMichielsens .pdf.

Milan Women's Bookstore Collective. 1990. Sexual Difference: A Theory of SocialSymbolic Practice. Bloomington: Indiana University Press.

Miller, Nancy K., ed. 1986. The Poetics of Gender. New York: Columbia University Press.

Montanaro, Mara. 2012. "A Françoise, ma Prof" [To Françoise, my teacher]. Le nouvel observateur, September 8. http://feministesentousgenres.blogs.nouve lobs.com/archive/2012/09/08/hommage-de-mara-montanaro-a.html.

Moore, Henrietta L. 1994. A Passion for Difference: Essays in Anthropology and Gender. Cambridge: Polity.

Nagl-Docekal, Herta, and Herlinde Pauer-Studer, eds. 1990. Denken der Geschlechterdifferenz: Neue Fragen und Perspektiven der feministischen Philosophie [Sexual difference theory: New questions and perspectives in feminist philosophy]. Vienna: Wiener Frauenverlag.

Neilson, Jim. 1995. "The Great PC Scare: Tyrannies of the Left, Rhetoric of the Right." In PC Wars: Politics and Theory in the Academy, ed. Jeffrey Williams, 60-89. New York: Routledge.

Oliver, Kelly, ed. 2000. French Feminism Reader. Lanham, MD: Rowman \& Littlefield.

Perrot, Michelle, ed. 1984. Une histoire des femmes est-elle possible? [Is a history of women possible?]. Marseille: Rivages.

Plateau, Nadine. 2011. "De la création littéraire, philosophique et féministe: Un entretien avec Françoise Collin" [On literary, philosophical and feminist creation: An interview with Françoise Collin]. Transmission(s) féministe(s), no. 1: 44-57. http://www.sophia.be/app/webroot/files/Collin\%20-\%20de\%20la $\% 20$ cre $\%$ CC $\% 8$ lation $\% 20-\% 20$ over $\% 20$ het $\% 20$ creatief $\% 20$ proces $\% 20-\% 20$ Nadine\%20Plateau.pdf.

Rich, Adrienne. 1976. Of Woman Born: Motherhood as Experience and Institution. New York: Norton. 
Rochefort, Florence, and Danielle Haase-Dubosc. 2001. "Entretien avec Françoise Collin: Philosophe et intellectuelle féministe" [Interview with Françoise Collin: Philosopher and feminist intellectual]. Clio, no. 13: 195-210.

Said, Edward. 1983. "Travelling Theory." In The World, the Text, and the Critic, 226-47. Cambridge, MA: Harvard University Press.

Santa Cruz, Maria Isabel, Ana María Bach, María Luisa Femenías, Alicia Gianella, and Margarita Roulet, eds. 1994. Mujeres y filosofía: Teoría filosófica de género [Women and philosophy: Philosophical theory of gender]. Buenos Aires: Centro Editor de América Latina.

Schor, Naomi. 1987. Reading in Detail: Aesthetics and the Feminine. New York: Methuen.

Scott, Joan Wallach. 1999. Gender and the Politics of History. New York: Columbia University Press.

- 2007. The Politics of the Veil. Princeton, NJ: Princeton University Press.

Seyrig, Delphine. 1983. "Etre bien avec les femmes" [Being at ease with women]. Les cabiers du Grif, no. 28: 75-83.

Spivak, Gayatri Chakravorty. 2003. Death of a Discipline. New York: Columbia University Press.

Sprinker, Michael 1995. "The War against Theory." In PC Wars: Politics and Theory in the Academy, ed. Jeffrey Williams, 149-71. New York: Routledge.

Stanton, Domna C. 1980. "Language and Revolution: The Franco-American Disconnection." In Eisenstein and Jardine 1980, 73-87.

ed. 1987. The Female Autograph: Theory and Practice of Autobiography from the Tenth to the Twentieth Century. Chicago: University of Chicago Press.

Stimpson, Catharine R. 1989. Where the Meanings Are. New York: Routledge.

Vance, Carole S., ed. 1984. Pleasure and Danger: Exploring Female Sexuality. Boston: Routledge \& Kegan Paul.

Vandelac, Louise. 1977a. "La crise, le travail ménager et les femmes italiennes" [Crisis, housework, and Italian women]. Les cahiers du Grif, no. 16: 5-18.

_. 1977b. "Mise au point" [Focus]. Les cahiers du Grif, nos. 17-18: 88.

Van der Tuin, Iris. 2009a. "'Jumping Generations': On Second- and Third-Wave Feminist Epistemology.” Australian Feminist Studies 24(59):17-31.

_. 2009b. "On Third-Wave Feminism's Generational Logic and Practices of Teaching Gender Studies." In Teaching with the Third Wave: New Feminists' Explorations of Teaching and Institutional Contexts, ed. Daniela Gronold, Brigitte Hipfl, and Linda Lund Pedersen, 17-36. Utrecht: ATHENA3.

$\rightarrow$ Varda, Agnès. 1976. "Je t'écris, te parle cinéma" [I want to write and talk to you about cinema]. Les cahiers du Grif, no. 13: 34-40.

West, Cornell. 1994. Prophetic Thought in Postmodern Times. Monroe, ME: Common Courage.

Williams, Jeffrey. 1995. "Introduction." In PC Wars: Politics and Theory in the Academy, ed. Jeffrey Williams, 1-10. New York: Routledge. 